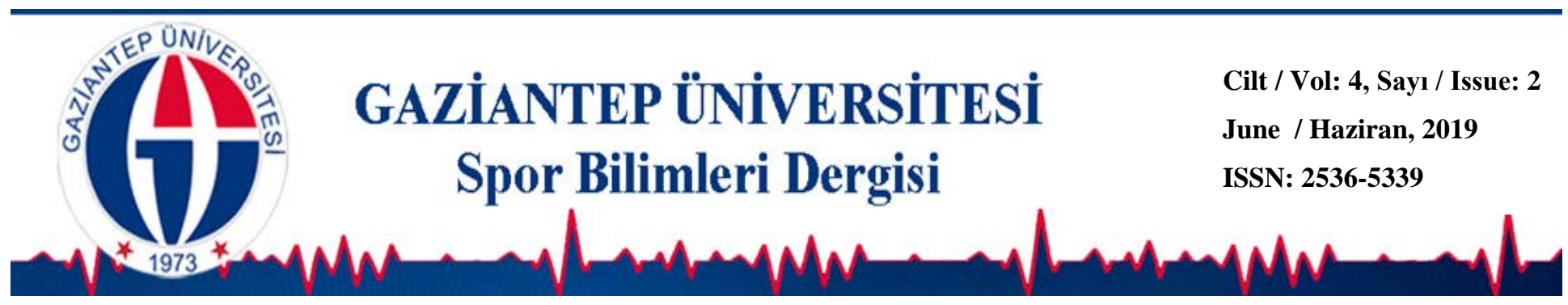

\title{
Atlet ve Kayaklı Koşucularda Yapılan Düzenli Antrenmanların Bazı Kan Parametrelerine Etkisi
}

\author{
Kürşat HAZAR ${ }^{1 *}$ (D) Harun $\mathrm{AKYOL}^{2}$ (D) \\ ${ }^{1}$ Muğla Sitkı Koçman Üniversitesi, $M U \breve{G} L A$ \\ ${ }^{2}$ Ağrı Gençlik ve Spor İl Müdürlüğü, $A \breve{G} R I$
}

DOI: 10.31680/gaunjss.550225

Orijinal Makale / Original Article Geliș Tarihi / Received: 06.04.2019

Kabul Tarihi / Accepted: 18.04.2019

Yayın Tarihi / Published: 28.06.2019

\section{Öz}

Atlet ve kayaklı koşucularda yapılan düzenli antrenmanların bazı kan parametrelerine etkisinin incelenmesi amacıyla yapılan bu çalışmaya; yaş ortalamaları 20,88 yıl, boy ortalamaları 1,71 m, vücut ağırlıkları 55,55 kg olan orta mesafe koşucusu 9 sporcu, yaş ortalamaları 20,62 yıl, boyları 1,74 m, vücut ağırlıkları 64,12 kg olan 8 kayaklı koşucu olmak üzere toplamda 17 elit düzey erkek sporcu katılmıştır. Katılımcılara sırasıyla; Bir yıl ara ile Boy ve vücut ağırlık ölçümleri ve kan analizleri yapılmıştır. Analizler sonucu antrenmanla alakalı olduğu düşünülen WBC, RBC, HGB, HCT, MCV, MCH, MCHC, PLT, serum demir ve demir bağlama değerlerine bakılmıştır. Elde edilen verilerin istatistiksel analizleri kişisel bilgisayarda SPSS 21.00 paket programında yapılmıştır. Tüm verilerde aritmetik ortalama ve standart sapmaları hesaplanmıştır. Araştırma gurubunun birinci ve ikinci ölçüm değerlerine ait karşılaştırma analizleri parametrik testlerden Paired Samples t test yöntemi ile farklı gurupların karşılaştırmaları ise bağımsız guruplarda $t$ test yöntemi ile yapılarak anlamlılık düzeyi $p<0,05$ olarak kurgulanmıştır. Yapılan istatistiksel analizler sonucunda koşucuların ve kayaklı koşucuların HGB, MCV ve MCHC parametrelerine ait birinci ve ikinci ölçüm değerleri arasında anlamlı farklılık olduğu tespit edilmiştir $(p<0,05)$.Koşucuların ve kayaklı koşucuların ikinci ölçüm değerleri birinci ölçüm değerlerinden daha yüksek bulunmuştur. Orta mesafe koşucuları ve kayaklı krosçularda uzun süreli yapılan düzenli antrenmanların HGB, MCV (Ortalama Alyuvar Hacmi) ve MCHC (Ortalama Alyuvar Hemoglobin Konsantrasyonu) parametreleri üzerinde artışa neden olduğu tespit edilmiştir.

Anahtar kelimeler: Atlet ve kayaklı koşucu, antrenman, kan parametreleri

\section{The Effect of Regular Training on Some Blood Parameters of Athletes and Cross- Country Skiers}

\section{Abstract}

In this study where the aim is to investigate the effect of regular training on some blood parameters of athletes and cross-country skiers, participants were a total of 17 elite male athletes that 9 of them were middle distance runners whose mean age was 20,88 years, mean height was $1,71 \mathrm{~m}$, mean bodyweight was $55,55 \mathrm{~kg} ; 8$ of them were cross-country skiers whose mean age was 20,62 years, mean height was $1,74 \mathrm{~m}$, mean bodyweight was $64,12 \mathrm{~kg}$. Participants were subject to height and bodyweight measurements and blood analyses, respectively with an interval of one year. WBC, RBC, HGB, HCT, MCV, MCH, MCHC, PLT, serum iron, and iron binding values, that were thought to be related to training as a result of analyses, were surveyed. The statistical analysis of the obtained data was done on a personal computer using the package program SPSS 21.00. Arithmetic means and standard deviations of all data were calculated. The comparative analyses of the first and the second measurement values of the research group were done with paired samples t-test, the comparison of different groups was done with independent samples t-test and the significance level was found to be $p<0,05$. According to the results of the conducted statistical analyses, it was determined that there is a significant difference between the first and the second measurement values of HGB, MCV, and MCHC parameters of the runners and the crosscountry skiers $(p<0,05)$. The second measurement values of the runners and the cross-country skiers were found to be higher than their first measurement values.It was determined that long-term regular training caused the HGB, MCV (Mean Corpuscular Volume), and MCHC (Mean Cell Hemoglobin Concentration) parameters to increase on the middle distance runners and the cross-country skiers.

Keywords: Athletes and cross-country skiers, training, blood parameters

\footnotetext{
* Sorumlu Yazar: Kürşat HAZAR
}

E-mail: kursathazar@hotmail.com 


\section{Giriş}

Günümüzde spor bilimindeki gelişmeler doğrultusunda yapılan araştırmaların amaçlarından biride performansın bir adım daha ileriye taşınmasıdır. Sportif performans; yapılması gereken bir atletik görevin yerine getirilmesi esnasında başarı elde edilmesi için ortaya konulan çabaların tümü olarak tanımlanabilir (Bayraktar ve Kurtoğlu 2004). Sportif performans en kısa zamanda en yüksek verimin elde edilmesi için sonucu etkileyen birçok faktörle beraber bir bütün olarak ele alınmalı ve değerlendirilmelidir.

$\mathrm{Bu}$ faktörlerden biride atlet ve kayaklı koşucuların fizyolojik özelliklerinin bilinmesidir. Atletizmde performansa etki eden faktörler oldukça çeşitli ve karmaşıktır. Bunlar genel olarak içsel ve dışsal faktörler olarak ikiye ayrılır. İçsel faktörler daha çok doğuştan var olan, kısmen kalıtsal, bireyin yaşamı içerisinde değişikliğe uğrayabilen ve dışarıdan etki imkânı sınırlı olabilen faktörlerdir. Yaş, cinsiyet postürel özellik, anatomik ve fizyolojik yapı bunlardan bazılarıdır (Bayraktar ve Kurtoğlu, 2009). Kayaklı koşu sporcularının özelliklerine bakıldığında ise antrenmanların; kardiyovasküler sistemi önemli ölçüde zorlayan, yarışma esnasında tüm kasların çalışmasını gerektiren bir yeterlilikte olması gerekir. Bu özellikleri geliştirmek ve koruyabilmek için bazı fiziksel ve fizyolojik özelliklere intiyaç vardır. Bunlardan birisi de en yüksek Max VO2'ye sahip olunmasıdır. Max VO2'nin anaerobik eşik değerinde oksijen tüketimi açısından ilişkili olduğu, performansa karşılık gelen oksijenin sağlanarak laktat birikmesinin önüne geçilebildiği bilinmektedir (Sandbakk ve Holmberg, 2014).

Egzersizde ventilasyon, kardiyak output, sistemik ve pulmoner kan akımının birbirleri ile uyumlu etkileşimi sunucunda; iskelet kaslarına olan metabolik ihtiyacın karşılanması gerekir. Normal şartlara göre iskelet kaslarının egzersiz esnasında metabolizma hızı yaklaşık 50 kat artış göstermektedir (Wasserman ve ark., 2011). Düzenli ve uzun süre yapılan antrenmanların sporcuların hematolojik parametrelerinde değişikliğe neden olduğu bilinirken, bazı araştırmacılar ise egzersizin kan volümünü artırdığını bazıları da değiştirmediğini ifade etmektedirler (Günay ve ark., 2006).

Sporcularda yoğun egzersiz sırasında ve sonrasında hematolojik parametrelerde, sporcunun antrenman durumu, yaş, cinsiyet, çevresel şartlar ve beslenme durumu gibi farklılıklardan dolayı hematolojik değişiklikler olabilmektedir 
(Beydağı ve ark., 1994). Özellikle uzun süreli ve yoğun egzersiz programları uygulayan sporcularda HGB ve HCT değerlerinde düşüş olmakta ve bu durum sporcu anemisi olarak değerlendirilmektedir (Ünal, 1998). Egzersizin organizma üzerindeki öncelikle etkisi dokulara olan oksijen intiyacını artıımasıdır. Oksijene olan intiyaç asıl olarak kalp debisindeki artışla karşılanır. Dolayısıyla oksijene olan gereksinimdeki artış kalp debisindeki artışla paralel olarak devam eder. Bunun yanında oksijen tüketimini kolaylaştıran başka değişikliklerde olur. Bunların başında hemoglobinin dokularda oksijene olan afinitesinde azalma meydana gelir. Bu durum arteriyovenöz oksijen farkında azalmaya neden olur (Uzun, 2016).

Egzersiz sırasında solunum hacim ve frekansında belirgin bir düzeyde değişim meydana gelirken, antrenmanlarla maksimal aerobik metabolizmadaki $\mathrm{O} 2$ tüketim hızında ise artış meydana gelmektedir (Tamer, 1995). Performansın arttırılmasında önemli olan efora karşııık gelen maksimal oksijen tüketiminin sağlanmasıdır. Koşucu ve kayaklı krosçularda uzun süre yapılan antrenmanların özellikle oksijen taşıma ile ilgili hematolojik parametreleri üzerinde herhangi bir değişikliğe neden olup olmadığının bilinmesi önemli görülürken yapılan bu çalışma; Atlet ve kayaklı koşucularda yapılan düzenli antrenmanların bazı kan parametrelerine etkisinin incelenmesi amacıyla ele alınmıştır.

\section{Yöntem}

\section{Katılımcılar}

$\mathrm{Bu}$ çalışmaya herhangi bir sağlıksal engeli olmayan, alkol ve sigara kullanmayan ve bir yıl boyunca aynı antrenmanları uygulayan yaş ortalamaları 20,88 yıl, boy ortalamaları $1,71 \mathrm{~m}$, vücut ağırlıkları $55,55 \mathrm{~kg}$ olan 9 orta mesafe koşucusu, yaş ortalamaları 20,62 yıl, boyları 1,74 m, vücut ağırlıkları 64,12 kg olan 8 kayaklı koşucu olmak üzere toplamda 17 elit düzey erkek sporcu gönüllü olarak katılmıştır. Çalışmada kan örneği alınan sporcu sayısı fazla olmasına rağmen daha sonra bir yıl boyunca düzenli antrenman yapan sporcu sayısında azalma olduğundan çalışmaya 17 katılımcı ile devam edilmiştir.

\section{Verilerin Toplanması}

Katıııcılara sırasıyla; Boy ve vücut ağırlık ölçümleri ve kan analizleri yapılmıştır. 
Boy ve Vücut Ağırlık Ölçümleri: : katılımcıların boy ölçümleri hassaslık derecesi $0,01 \mathrm{~cm}$ olan Holtain Limited marka boy ölçer ile vücut ağılıkları ise hassaslık derecesi $0,1 \mathrm{~kg}$ olan Angel marka elektronik baskül ile ölçülmüştür.

Kan Analizleri: katılımcıların kan örnekleri her iki gurup için bir yıl ara ile aralık ayının son haftasına denk gelecek şekilde özel bir hastanede uzman kişi tarafından alınarak aynı hastanenin laboratuvarında (Olympus AU 600 Model) cihazla biyokimyasal parametrelerine bakıldı. Tam kan sayımları ise (Medanic CA 530 Model) cihazla analiz edilmiştir. Analizler sonucu antrenmanla alakalı olduğu düşünülen WBC, RBC, HGB, HCT, MCV, MCH, MCHC, PLT, serum demir ve demir bağlama değerlerine bakılmıştır.

\section{Verilerin Analizi}

Elde edilen verilerin istatistiksel analizleri kişisel bilgisayarda SPSS 21.00 paket programında yapılmıştır. Elde edilen verilere normallik sınaması yapılmıştır. Normal dağılım gösteren verilerde aritmetik ortalama ve standart sapmaları hesaplanmıştır. Araştırma grubunun birinci ve ikinci ölçüm değerlerine ait karşılaştırma analizleri parametrik testlerden Paired Samples t test yöntemi ile farklı gurupların karşılaştırmaları ise bağımsız guruplarda $t$ test yöntemi ile yapılarak anlamlılık düzeyi $p<0,05$ olarak kurgulanmıştır.

\section{Uygulanan Antrenman Programı}

$\mathrm{Bu}$ çalışmaya katılan sporcular atletizm branşında orta mesafe koşucuları, kayak branşında ise kayaklı koşu branşı ve alp disiplini branşı sporcularıdır. Sporcular atletizm ve kayaklı koşu branşında yer alan elit düzey sporcular olarak yılın belirli yarışma dönemlerine göre çeşitli antrenman yapmışlardır. Çalışmaya katılan atletizm branşındaki sporcular; sezon başlarında koşu, koşu dirilleri ile başlayan antrenmanlar kondisyon ve kuvvet antrenmanları ile, Sezon ortasında mesafe antrenmanları, kuvvette dayanıklılık ve tepe antrenmanları ile devam etmişlerdir. Yarışma dönemlerinde ise hız kuvvet, süratte devamlılık ve kapsamın daraltılıp şiddettin arttığı antrenmanlar ile yarışmalara katılmışlardır. Çalışmaya katılan kayak branşındaki sporcular ise; Sezon başlarında koşu, teknik çalışmalar, tekerlekli kayak antrenmanları yapmışlardır. Sezon ortasında kış sezonuna hazırlık olarak batonlu imitasyon, kondisyon, tepe antrenmanları, tekerlekli kayak antrenmanları 
yapmışlardır. Kış sezonu yarışma döneminde ise kar üzerinde yapılan antrenmanlarda hız kuvvet, sürat, süratte devamlılık antrenmanları ile sezonu geçirmişlerdir.

\section{Bulgular}

Tablo 1. Katıımcılara Ait Tanımlayıcı İstatistikler

\begin{tabular}{rllcccc}
\hline Guruplar & Değişkenler & N & Minimum & Maximum & \pm & Ss \\
\hline \multirow{3}{*}{ Koşucular } & Yaş & 9 & 20,00 & 22,00 & 20,88 &, 781 \\
\cline { 2 - 7 } & Boy & 9 & 1,65 & 1,76 & 1,71 &, 043 \\
\cline { 2 - 7 } & Vücut ağırlığı & 9 & 52,00 & 61,00 & 55,55 & 2,505 \\
\hline \multirow{3}{*}{$\begin{array}{c}\text { Kayaklı } \\
\text { Koşucular }\end{array}$} & Yaş & 8 & 20,00 & 22,00 & 20,62 &, 744 \\
\cline { 2 - 7 } & Boy & 8 & 1,68 & 1,80 & 1,74 &, 048 \\
\cline { 2 - 7 } & Vücut ağırlığı & 8 & 60,00 & 66,00 & 64,12 & 2,587 \\
\hline
\end{tabular}

Tablo 2. Koşucuların Kan Parametrelerine İlişkin Birinci ve İkinci Ölçüm Sonuçlarının Karşılaştırması

\begin{tabular}{|c|c|c|c|c|c|c|}
\hline Guruplar & Değişkenler & $\mathrm{N}$ & $\overline{\bar{x}}$ & S.S & $\mathrm{t}$ & $p$ \\
\hline \multirow{20}{*}{ 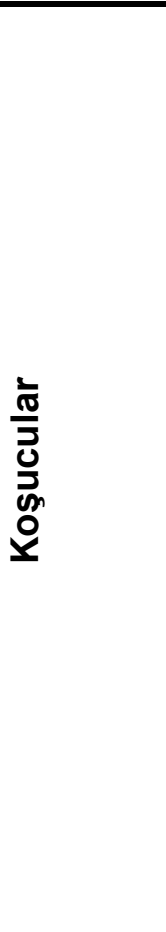 } & WBC1.Ölçüm & 9 & 5,88 & 1,765 & \multirow[b]{2}{*}{1,660} & \multirow[b]{2}{*}{, 135 } \\
\hline & WBC 2.Ölçüm & 9 & 7,24 & 1,271 & & \\
\hline & RBC 1. Ölçüm & 9 & 4,78 & ,324 & \multirow[b]{2}{*}{1,944} & \multirow[b]{2}{*}{,088 } \\
\hline & RBC 2. Ölçüm & 9 & 5,02 & ,328 & & \\
\hline & HGB 1. Ölçüm & 9 & 13,95 & ,965 & \multirow[b]{2}{*}{2,982} & \multirow[b]{2}{*}{, $018^{\star}$} \\
\hline & HGB 2. Ölçüm & 9 & 15,15 & 1,233 & & \\
\hline & HCT 1. Ölçüm & 9 & 42,48 & 2,516 & \multirow[b]{2}{*}{,428 } & \multirow{3}{*}{,680 } \\
\hline & HCT 2. Ölçüm & 9 & 42,94 & 3,483 & & \\
\hline & MCV 1.Ölçüm & 9 & 85,22 & 1,922 & \multirow[b]{2}{*}{$-2,478$} & \\
\hline & MCV 2.Ölçüm & 9 & 88,77 & 3,231 & & ,038* \\
\hline & MCH 1.Ölçüm & 9 & 29,14 & ,685 & \multirow[b]{2}{*}{1,877} & \multirow[b]{2}{*}{,097 } \\
\hline & MCH 2.Ölçüm & 9 & 30,18 & 1,344 & & \\
\hline & MCHC1.Ölçüm & 9 & 32,76 & ,664 & \multirow[b]{2}{*}{8,673} & \multirow{3}{*}{, $000^{\star *}$} \\
\hline & MCHC2.Ölçüm & 9 & 35,38 &, 531 & & \\
\hline & PLT 1. Ölçüm & 9 & 246,00 & 59,148 & \multirow[b]{2}{*}{,- 731} & \\
\hline & PLT 2.Ölçüm & 9 & 259,22 & 33,379 & & ,486 \\
\hline & Demir1. Ölçüm & 9 & 105,47 & 15,194 & \multirow[b]{2}{*}{1,528} & \multirow[b]{2}{*}{ 165 } \\
\hline & Demir2. Ölçüm & 9 & 125,88 & 32,307 & & \\
\hline & DemirBağlama1 & 9 & 251,55 & 37,71973 & \multirow[b]{2}{*}{,098 } & \multirow[b]{2}{*}{,924 } \\
\hline & Demir bağlam2 & 9 & 249,33 & 64,36808 & & \\
\hline
\end{tabular}

$\mathrm{P}<0,01^{\star \star}, \mathrm{p}>0,05$

Tablo 2' ye bakıldığında koşucuların HGB, MCV ve MCHC parametrelerine ait birinci ve ikinci ölçüm değerleri arasında anlamlı farklılık vardır $(p<0,05)$.Koşucuların ikinci ölçüm değerleri birinci ölçüm değerlerinden daha yüksektir. Ayrıca WBC, RBC, $\mathrm{HCT}, \mathrm{MCH}, \mathrm{MCHC}, \mathrm{PLT}$, demir ve demir bağlama parametrelerine ait bir ve ikinci 
Hazar K., Akyol H. (2019). Atlet ve Kayaklı Koşucularda Yapılan Düzenli Antrenmanların Bazı Kan Parametrelerine Etkisi. Gaziantep Üniversitesi Spor Bilimleri Dergisi, 4(2), 211-221.

ölçüm değerleri arasında ise istatistiksel olarak anlamlı farklılık olmadığı tespit edilmiştir $(p>0,05)$.

Tablo 3. Kayaklı Koşucuların Kan Parametrelerine Illişkin Birinci ve İkinci Ölçüm Değerlerinin Karşılaştırması

\begin{tabular}{|c|c|c|c|c|c|c|}
\hline Guruplar & Değişkenler & $\mathrm{N}$ & $\overline{\bar{x}}$ & S.S & $\mathrm{t}$ & $p$ \\
\hline \multirow{20}{*}{ 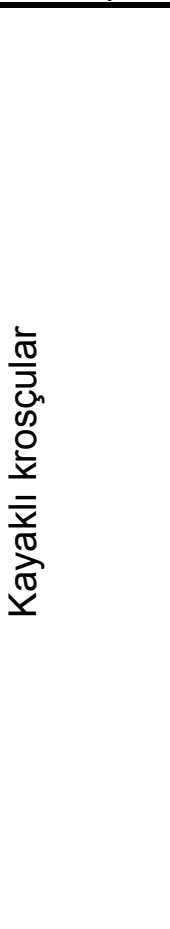 } & WBC1.Ölçüm & 8 & 7,01 & 1,644 & \multirow[b]{2}{*}{ 855, } & \multirow[b]{2}{*}{,421 } \\
\hline & WBC 2.Ölçüm & 8 & 7,53 & 1,027 & & \\
\hline & RBC 1. Ölçüm & 8 & 5,01 & ,318 & \multirow[b]{2}{*}{,943 } & \multirow[b]{2}{*}{,377 } \\
\hline & RBC 2. Ölçüm & 8 & 5,18 & ,292 & & \\
\hline & HGB 1. Ölçüm & 8 & 14,30 & ,952 & \multirow[b]{2}{*}{1,298} & \multirow[b]{2}{*}{,235 } \\
\hline & HGB 2. Ölçüm & 8 & 14,85 & ,991 & & \\
\hline & HCT 1. Ölçüm & 8 & 42,92 & 3,343 & \multirow[b]{2}{*}{,- 540} & \multirow[b]{2}{*}{,606 } \\
\hline & HCT 2. Ölçüm & 8 & 43,61 & 2,829 & & \\
\hline & MCV 1.Ölçüm & 8 & 82,87 & 6,266 & \multirow[b]{2}{*}{$-1,488$} & \multirow[b]{2}{*}{, 180} \\
\hline & MCV 2.Ölçüm & 8 & 87,25 & 4,920 & & \\
\hline & $\mathrm{MCH}$ 1.Ölçüm & 8 & 28,59 & 1,958 & \multirow[b]{2}{*}{,- 017} & \multirow[b]{2}{*}{,987 } \\
\hline & MCH 2.Ölçüm & 8 & 28,61 & 1,989 & & \\
\hline & MCHC1.Ölçüm & 8 & 32,81 & 1,190 & \multirow{3}{*}{3,193} & \multirow{3}{*}{, $015^{\star}$} \\
\hline & MCHC2.Ölçüm & 8 & 34,50 &, 760 & & \\
\hline & PLT 1. Ölçüm & 8 & 270,12 & 49,157 & & \\
\hline & PLT 2.Ölçüm & 8 & 272,75 & 40,924 &,- 110 & ,916 \\
\hline & Demir1. Ölçüm & 8 & 88,15 & 39,711 & \multirow[b]{2}{*}{2,089} & \multirow[b]{2}{*}{,075, } \\
\hline & Demir2. Ölçüm & 8 & 121,87 & 41,004 & & \\
\hline & DemirBağlama1 & 8 & 268,75 & 77,171 & \multirow[b]{2}{*}{$-1,113$} & \multirow[b]{2}{*}{,302 } \\
\hline & Demir bağlama2 & 8 & 237,62 & 51,657 & & \\
\hline
\end{tabular}

$\mathrm{P}>0,05$

Tablo 3' te kayaklı Koşucuların MCHC parametrelerine ait birinci ve ikinci ölçüm değerleri arasında anlamlı farklıık vardır $(p<0,05)$.Kayaklı krosçuların ikinci ölçüm değerleri daha yüksektir. Ayrıca WBC, RBC, HGB, HCT, MCV, MCH, PLT, demir ve demir bağlama parametrelerine ait birinci ve ikinci ölçüm değerleri arasında ise istatistiksel olarak anlamlı farklılık olmadığı görülmektedir $(p>0,05)$. 
Tablo 5. Katıımcıların Kan Değerlerine İlişkin Birinci Ölçüm Sonuçlarının Karşılaştırması

\begin{tabular}{|c|c|c|c|c|c|c|}
\hline Değişkenler & Guruplar & $\bar{N}$ & $\overline{\bar{X}}$ & $\mathrm{Sd}$ & $\mathrm{t}$ & $p$ \\
\hline \multirow[t]{2}{*}{ WBC (10*3/uL) } & Koşucular & 9 & 5,88 & 1,271 & \multirow[b]{2}{*}{$-1,987$} & \multirow[b]{2}{*}{,066 } \\
\hline & Kayaklı Koşucular & 8 & 7,01 & 1,027 & & \\
\hline \multirow[t]{2}{*}{ RBC (10*6/u L) } & Koşucular & 9 & 4,78 & ,328 & \multirow[b]{2}{*}{$-1,54$} & \multirow[b]{2}{*}{, 144 } \\
\hline & Kayaklı Koşucular & 8 & 5,01 & ,292 & & \\
\hline \multirow[t]{2}{*}{ HGB (g/d L) } & Koşucular & 9 & 13,95 & 1,233 & \multirow[b]{2}{*}{,- 629} & \multirow[b]{2}{*}{, 539} \\
\hline & Kayaklı Koşucular & 8 & 14,30 &, 991 & & \\
\hline \multirow[t]{2}{*}{ HCT (\%) } & Koşucular & 9 & 42,48 & 3,483 & \multirow[b]{2}{*}{,- 724} & \multirow[b]{2}{*}{,480 } \\
\hline & Kayaklı Koşucular & 8 & 43,61 & 2,829 & & \\
\hline \multirow[t]{2}{*}{$\overline{M C V}(\mathrm{Fl})$} & Koşucular & 9 & 88,77 & 3,231 & \multirow[b]{2}{*}{,765 } & \multirow[b]{2}{*}{,456 } \\
\hline & Kayak Koşucular & 8 & 87,25 & 4,920 & & \\
\hline \multirow[t]{2}{*}{$\mathrm{PLT} 10^{\star} / \mathrm{u} \mathrm{L}$} & Koşucular & 9 & 259,22 & 33,379 & \multirow[b]{2}{*}{,- 751} & \multirow[b]{2}{*}{,465 } \\
\hline & Kayaklı Koşucular & 8 & 272,75 & 40,924 & & \\
\hline \multirow[t]{2}{*}{ Demir ug/dL } & Koşucular & 9 & 105,47 & 32,307 & \multirow[b]{2}{*}{ 974 } & \multirow[b]{2}{*}{,346 } \\
\hline & Kayaklı Koşucular & 8 & 88,15 & 41,004 & & \\
\hline \multirow{2}{*}{$\begin{array}{l}\text { Demir bağlama } \\
\text { (ug/dL ) }\end{array}$} & Koşucular & 9 & 249,33 & 64,368 & \multirow[b]{2}{*}{ - 680} & \multirow[b]{2}{*}{,507 } \\
\hline & Kayaklı Kossucular & 8 & 268,75 & 51,657 & & \\
\hline
\end{tabular}

Tablo 5'e bakıldığında guruplarda yer alan katılımcıların kan değerlerine ilişkin WBC, RBC, HGB, HCT, MCV, PLT, demir ve demir bağlama birinci ölçüm değerleri arasında anlamlı farklılık yoktur $(p>0,05)$.

Tablo 4. Katılımcıların Kan Değerlerine İlişkin İkinci Ölçüm Sonuçlarının Karşılaştırması

\begin{tabular}{|c|c|c|c|c|c|c|}
\hline Değişkenler & Guruplar & $\mathrm{N}$ & $\overline{\overline{\mathrm{X}}}$ & Sd & $\mathrm{t}$ & $\mathrm{p}$ \\
\hline \multirow[t]{2}{*}{ WBC $(10 * 3 / u$ L) } & Koşucular & 9 & 7,24 & 1,765 & & \\
\hline & Kayaklı Koşucular & 8 & 7,53 & 1,644 &,- 353 &, 729 \\
\hline \multirow[t]{2}{*}{ RBC (10*6/u L) } & Koşucular & 9 & 5,02 & 324 & & \\
\hline & Kayaklı Koşucular & 8 & 5,18 & 318 & $-1,033$ & ,318 \\
\hline \multirow[t]{2}{*}{ HGB (g/d L) } & Koşucular & 9 & 15,15 & ,965 & & \\
\hline & Kayaklı Koşucular & 8 & 14,85 & ,952 & ,643 &, 530 \\
\hline \multirow[t]{2}{*}{ HCT (\%) } & Koşucular & 9 & 42,94 & 2,516 & & \\
\hline & Kayaklı Koşucular & 8 & 42,92 & 3,343 & 014 & ,989 \\
\hline \multirow[t]{2}{*}{$\mathrm{MCV}(\mathrm{Fl})$} & Koşucular & 9 & 85,22 & 1,922 & & \\
\hline & Kayaklı Koşucular & 8 & 82,87 & 6,266 & 1,072 & ,301 \\
\hline \multirow[t]{2}{*}{ PLT (10*/u L) } & Koşucular & 9 & 246,00 & 59,148 & & \\
\hline & Kayaklı Koşucular & 8 & 270,10 & 49,157 &,- 907 & 379 \\
\hline \multirow[t]{2}{*}{ Demir (ug/Dl) } & Koşucular & 9 & 125,89 & 15,194 & & \\
\hline & Kayaklı Koşucular & 8 & 121,80 & 39,711 & ,282 & ,782 \\
\hline \multirow{2}{*}{$\begin{array}{l}\text { Demir bağlama } \\
\text { (ug/DI) }\end{array}$} & Koşucular & 9 & 251,56 & 37,719 & & \\
\hline & Kayaklı Koşucular & 8 & 237,60 & 77,171 & 482 & ,637 \\
\hline
\end{tabular}

Tabloda görüldüğü gibi guruplarda yer alan koşucu ve kayaklı Koşucuların ikinci ölçüm değerlerinde WBC, RBC, HGB, HCT, MCV, PLT, demir ve demir bağlam parametreleri arasında anlamlı farklıık olmadığı görülmektedir $(p>0,05)$. 


\section{Tartışma ve Sonuç}

Atlet ve kayaklı koşucularda yapılan düzenli antrenmanların bazı kan parametrelerine etkisinin incelenmesi amacıyla yapılan bu çalışmada; Koşucuların HGB, MCV ve MCHC, kayaklı Koşucuların ise sadece MCHC parametrelerine ait birinci ve ikinci ölçüm değerleri arasında anlamlı farklılık tespit edilmiştir $(p<0,05)$. Koşucuların ve kayaklı Koşucuların kinci ölçüm değerleri birinci ölçüm değerlerinden daha yüksek bulunmuştur. Ayrıca katılımcıların eritrosit değerlerinde belli oranda artış olmasına karşılık WBC, RBC, HCT, MCH, PLT, demir ve demir bağlama parametrelerine ait bir ve ikinci ölçüm değerleri arasında ise istatistiksel olarak anlamlı farkılık olmadığı tespit edilmiştir $(p>0,05)$.

Kasap ve ark., 12 haftalık yetenek sınavına hazırlanan öğrenci adaylarının yapmış oldukları antrenmanların hematolojik parametreler üzerine etkisi adlı çalışmasında katıımcıların 12 hafta sonundaki ölçümlerinde (RBC, HGB, HCT,) değerlerinde anlamlı artış olduğunu tespit etmişlerdir (Kasap ve ark.,2018). Baltacı ve ark., tarafından yapılan çalışmada uzun süreli yapılan egzersizin basketbolcuların eritrosit, hematokrit MCV ve MCHC değerlerini kontrol grubuna oranla daha yüksek olduğunu tespit etmişlerdir (Baltacı ve ark.,1998). Arslan ve arkadaşları atletler üzerinde yapmış oldukları çalışmalarında MCV değerlerini kontrol gurubuna göre önemli ölçüde yüksek olduğunu bildirmişlerdir. İbiş ve ark., (2010), aerobik ve anaerobik egzersizlerin hematolojik parametrelere akut etkisi konulu çalışmalarında aerobik egzersiz sonrası hematolojik değerlerin hiç birinde anlamlı değişiklikler tespit edilmediğini, ancak anaerobik egzersizden hemen sonra HB, HCT, WBC değerlerinde anlamlı artışlar olduğu 24 saat sonra ise anlamlı düşüşler tespit etmişlerdir. Her iki egzersizin aynı zamanları karşılaştırıldığında ise anaerobik egzersizdeki artış ve azalmalar aerobik egzersize nazaran daha anlamlı olduğunu ifade etmişlerdir (İbiş ve ark., 2010).

Katılımcıların WBC, RBC, HCT, MCH, PLT, demir ve demir bağlama parametrelerine ait bir ve ikinci ölçüm değerleri arasında ise istatistiksel olarak anlamlı farklılık olmadığı tespit edilmiştir( $p>0,05)$. Egzersizin WBC değerlerini inceleyen araştırmalarda; Yeh ve ark., (2006), 12 hafta süre ile yapılan düzenli antrenmanlarda 14 erkek ve 23 kadın sporcuların 12 hafta öncesi ve sonrasında yapılan kan analizlerinde WBC değerlerinde anlamlı bir değişikliğin olmadığını bildirmişlerdir (Yeh ve ark., 2006). Banfi ve ark., (2006), 19 erkek rugby oyuncusunda 
kamp öncesi ve sonrası WBC düzeylerinde değişiklik olmadığını bildirmişlerdir. Mashiko ve ark., (2004), 25 sporcuya uygulanan 20 günlük kamp döneminin HCT düzeylerinde anlamlı olarak değişikliğe yol açmadığını (Mashiko ve ark., 2004), Green ve ark., (1996), 6 haftalık yüksek şiddetli interval antrenmanların HCT düzeylerinde bir değişime yol açmadığını, yoğun antrenman programı uygulayan atletlerde karakteristik olarak hematokrit değerlerinde düşüşe neden olmakta ve bu durum sporcu anemisi olarak bilinmektedir. Londean ve ark., ile Pouramir ve ark., erkek cimnastikçiler üzerinde yaptıkları çalışmada 10 haftalık bir egzersiz programının öncesi ve sonrasında alınan kan örneklerinde sporcuların ortalama eritrosit hacminde anlamlı bir değişiklik olmadığını tespit etmişlerdir (Londeann, 1978). Yapılan araştırmalarda Ünal (1998), 8 haftalık kronik aerobik egzersiz sonrasında PLT düzeylerinde önemli farklılık $(p>0,05)$ bulamamışlardır. Benzer bir çalışmada Ünal ve ark., (2002) sedanter deneklere uygulanan kronik egzersiz sonrasında PLT düzeylerinde anlamlı farklılık $(p>0,05)$ bulamamışlardır (Büyük yazı ve ark., 2002). Yapılan bir çok araştırmada akut maksimal bir egzersizin hemen sonrasında eritrosit parametrelerinde belirgin olarak görülen bu artışın egzersizden 46 saat sonra normal değerlerin altına indiği belirtilmiştir. Araştırmalarda bu artışın hemokonsantrasyon mekanizması ile açıklandığı dile getirilmiştir (Baltacı ve ark., 1990).

Literatüre bakıldığında uzun süreli egzersizin eritrosit parametrelerine nasıl bir etki oluşturduğuna dair herhangi bir fikir birliği bulunmamaktadır. Bu egzersizlerin hematolojik parametreler üzerinde nasıl bir etki yarattığının belirlenmesi ve diğer araştırmalarla mukayese edilmesi konu ile ilgili tartışmalara daha değişik yorumların getirilmesini sağlayacaktır. Yapılan bu çalışmada kan analizleri elit orta mesafe koşucuları ile kayaklı koşucularda bir yıl ara ile uygulanmıştır. Literatürde egzersizin hematolojik parametrelere olan kronik etkisine ilişkin oldukça sınırlı sayıda araştırma olduğundan bu çalışmanın bulguları benzer çalışmalarla desteklenmiştir. Araştırma bulgularında yer alan her iki gurubun HGB, MCV ve MCHC, değerlerindeki artışın nedeni koşu ve koşu branşlarında olan sporcuların O2'ye olan aşırı gereksinimlerine vücudun vermiş olduğu fizyolojik bir yanıt olabileceği düşünülmektedir.

Sonuç olarak, orta mesafe koşucuları ve kayaklı Koşucularda uzun süreli yapılan düzenli antrenmanların HGB, MCV (Ortalama Alyuvar Hacmi) ve MCHC 
(Ortalama Alyuvar Hemoglobin Konsantrasyonu) parametreleri üzerinde artışa neden olduğu tespit edilmiştir.

\section{Kaynaklar}

Baltacı, A. K., Ergene, N., \& Uysal, H. (1990). Çinkonun insan sağlığındaki rolü.SÜ Tıp Fak Derg. 6(4), 444-8.

Baltacı, A., Moğulkoç, R., Koç, S., Özmerdivenli, R. (1998). Sporcu Genç Kızlarda Bazı Hematolojik Parametreler İle Plazma Proteinleri Ve Serum Çinko, Kalsiyum, Fosfor Düzeyleri. Gazi Beden Eğitimi ve Spor Bilimleri Dergisi, 3 (2): 21-30.

Banfi G,Del Fablo M,Mauri C,Corsi Mm, Melegati G,et all, (2006). Hematological Parameters İn Higly Elite Rugby Players During A Competitive Season.Jun Pub Med -İndexed For Medline. 28( 3):183-8.

Bayraktar B, Kurtoğlu, M. (2009). Sporda Performans, Etkili Faktörler, Değerlendirilmesi ve Artırılması. Klinik Gelişim. 22 (1), 16-24.

Bayraktar B, Kurtoğlu M. (2004). Sporda performans ve performans artırma yöntemleri. Atasü T, Yücesir İ, eds. Doping ve futbolda performans artırma yöntemleri, İstanbul. 269-296.

Beydağı, H., Çoksevim, B., Temoçin, S (1994). Spor yapan ve yapmayan gruplarda bazı eritrositer parametrelere egzersizin etkisi, Gaziantep Üniversitesi Tıp Fak Derg, 5, $21-28$.

Büyükyazı, G., et al. "et al. (2002). Kronik Antrenmanın Yaşlılarda Serum Demir, Magnezyum, Hematolojik Ve Lipit Parametreleri Üzerine Etkisi." Spor Hek. Der, 37, 51-59.

Davidson, R. J. L., Robertson, J. D., Galea, G., \& Maughan, R. J. (1987). Hematological changes associated with marathon running. International journal of sports medicine, 8(01), 19-25.

Green, L. (1996). Mixed Motives and After-Acquired Evidence: Second Cousins Benefit from 20/20 Hindsight. Ark. L. Rev., 49, 211.

Günay. M, Tamer, K., \& Cicioğlu, İ. (2006). Spor Fizyolojisi ve Performans Ölçümü, Gazi Kitabevi, Baran Ofset, Ankara. ss:219-227. 
İbiş, S., Hazar, S., \& Gökdemir, K. (2010). Aerobik ve anaerobik egzersizlerin hematolojik parametrelere akut etkisi. Uluslararası İnsan Bilimleri Dergisi, 7(1), 71-81.

Londeann R. (1978). Low hematocrits during basic training athletes anemia. Nenld J. Med., 299: 1191-2.

Mashiko T, Umeda T, Nakaji S, Sugawara K ,et al. (2004)Effects Of Exercise On The Physical Condition Ofcollege Rugby Players Duri. ng Summer Training Camp Br J Sports Med;,38:186-190.

Sandbakk, O., \& Holmberg, HC., (2014). A Reappraisal of Success Factors For Olympic Cross-Country Skiing. International Journal of Sports Physiology and Performance. 9(1), 117-121.

Serin, E. (2015). Anaerobik dayanıkılık ile dikey sıçrama arasındaki ilişki (Doctoral dissertation, Selçuk Üniversitesi Sağlık Bilimleri Enstitüsü).

Tamer, K. (1995). Çeşitli koşu programlarının aerobik, anaerobik güç ve akciğer fonksiyonlarına etkileriyle ilişki düzeylerinin belirlenmesi. Performans Dergisi, 1(3), 32-39.

Uzun, M. (2016). kardiyovasküler sistem ve egzersiz, Journal of Cardiovascular Nursing, 7(Sup 2):48-53.

Ünal, M., \& All, A. (2001). Aerobik ve anaerobik akut egzersizlerin immun parametreler üzerindeki etkileri. İstanbul Tıp Fakültesi Dergisi, 64(3).

Wasserman K, Hansen JE, Sue DY, et al. (2011). Physiology of exercise. Principles of Exercise Testing and Interpretation: Including Pathophysiology and Clinical Applications. 5th ed. Wolters Kluwer Lippincott Williams \& Wilkins,.

Yeh, S. H., Chuang, H., Lin, L. W., Hsiao, C. Y., \& Eng, H. L. (2006). Regular tai chi chuan exercise enhances functional mobility and CD4CD25 regulatory $T$ cells. British journal of sports medicine, 40(3), 239-243. 